\title{
Microbial Degradation of Polyhydroxyalkanoates in Fresh Tropical Water
}

\author{
Svetlana V. Prudnikova a*, Anatoly N. Boyandin ${ }^{a, b}$, \\ Valery A. Karpov', Thị Mỹ Hiệp Lề, \\ Nikolay L. Filichev ${ }^{d}$ and Iosif I. Gitelson ${ }^{b}$ \\ ${ }^{a}$ Siberian Federal University \\ 79 Svobodny, Krasnoyarsk, 660041, Russia \\ ${ }^{b}$ Institute of Biophysics SB RAS \\ 50/50 Akademgorodok, Krasnoyarsk, 660036, Russia \\ ${ }^{c} A . N$. Severtsov Institute of Ecology and Evolution of $R A S$ \\ 33 Leninskij, Moscow, 119071, Russia \\ ${ }^{d}$ The Joint Russian-Vietnam Tropical Research and Test Center
} 30 Nguyễn Thiện Thuật, Tân Lập, Nha Trang, Khánh Hoà, Việt Nam

Received 12.01.2015, received in revised form 14.03.2015, accepted 24.05.2015

The biodegradation patterns of different polyhydroxyalkanoates (PHAs) was studied in freshwater tropical reservoirs of South Vietnam (Nha Trang), in an artificial still water reservoir and in running water of the River Kai. It was revealed the weight loss profiles of films and pellets in the River Kai did not depend on the chemical structure of the polymer samples; poly(3-hydroxybutyrate) and a copolymer of poly(3-hydroxybutyrate-co-3-hydroxyvalerate) degraded with the same intensity. The weight loss of homopolymer samples was faster in artificial reservoir. The study of the taxonomic variety of microorganisms in the fouling films of polymer samples showed differences in the dominant communities of PHA-degrading microorganisms. Among other organotrophs the proportion of PHAdepolymerase synthesizing bacteria was higher in the River Kai and ranging from 7 to $17 \%$ in different samples, in spite of that the taxonomic variety of PHA-degrading bacteria was less diverse. The PHAdegrading community of the River Kai was represented by Bacillus, Acinetobacter and Streptomyces, from artificial reservoir samples Bacillus, Pseudomonas, Corynebacterium, Mycobacterium and Actinobacteria was isolated. The PHA-degrading fungi-Aspergillus candidus and Verticillium albawere found only in the artificial reservoir.

Keywords: biodegradable polymers, polyhydroxyalkanoates (PHAs), biodegradation, degrading microorganisms.

DOI: 10.17516/1997-1389-2015-8-2-187-198.

(C) Siberian Federal University. All rights reserved

* Corresponding author E-mail address: sprudnikova@sfu-kras.ru 


\title{
Микробиологическая деградация \\ полигидроксиалканоатов в пресной воде тропиков
}

\author{
С.В. Прудникова ${ }^{\mathrm{a}}$, А.Н. Бояндин ${ }^{\mathrm{a}, \boldsymbol{\sigma}}$, В.А. Карпов ${ }^{\mathrm{B}}$, \\ Тхи Ми Хиеп Лег, Н.Л. Филичев \\ ${ }^{a}$ Сибирский федеральный университет \\ Россия, 660041, Красноярск, пр. Свободный, 79 \\ ${ }^{6}$ Институт биофизики СО РАН \\ Россия, 660036, Красноярск, Академгородок, 50/50
}

${ }^{8}$ Институт проблем экологии и эволючии им. А.Н. Севериова РАН

Россия, 119071, Москва, Ленинский пр., 33

'Российско-Вьетнамский Тропический научно-исследовательский и технологический иентр

Вьетнам, Кханьхоа, Нячанг, Нгуен Тхиен Тхуат, 30

Исследованы закономерности биодеградации образцов полигидроксиалканоатов (ПГА) различной химической структуры и морфологии в пресных тропических водоёмах Южного Вьетнама (2. Нячанг) - в искусственом бессточном бассейне и проточной воде реки Кай. Выявлено, что профили снижения массы плёнок и прессованных форм в реке Кай не зависели от химической структуры полимеров, образиы гомополимера 3-гидроксибутирата и сополимера 3-гидроксибутирата и 3-гидроксивалерата разрушались с одинаковой интенсивностью. В искусственном водоёме быстрее происходило разрушение образиов из гомополимера. Изучение таксономического разнообразия микроорганизмов в биоплёнках обрастания на поверхности образиов полимеров выявило различия в сообществах доминантных микроорганизмовдеструкторов. Доля бактерий-деструкторов, обладающих ПГА-деполимеразами, среди прочих органотрофов была выше в реке Кай, составляя от 7 до 17 \% на разных образиах, однако таксономический состав бактерий деструкторов был менее разнообразным. В реке Кай сообщество деструкторов было представлено бактериями родов Bacillus, Acinetobacter u Streptomyces, а в искусственном водоёме - представителями родов Bacillus, Pseudomonas, Corynebacterium, Mycobacterium, а также актинобактериями. Микромицеты-деструкторы были обнаружены только в искусственном водоёме - Aspergillus candidus u Verticillium alba.

Ключевые слова: биоразрушаемые полимеры, полигидроксиалканоаты (ПГА), биодеградация, микроорганизмы-деструкторы.

\section{Введение}

Одним из эффективных приёмов защиты окружающей среды от накопления тупиковых отходов является использование вместо синтетических полиолефинов биоразлагаемых биопластиков, к которым относятся по- лигидроксиалканоаты (ПГА) - микробные биополимеры. Возможность синтезировать ПГА разной химической структуры позволяет получать изделия с разнообразными физикомеханическими свойствами, которые будут биодеградировать в окружающей среде 
с образованием нетоксичных продуктов. Скорости деградации таких изделий при попадании в почву или водоёмы будут зависеть от множества факторов - химических и физических характеристик полимеров, климато-географических условий, структуры микробных сообществ почвенных и водных экосистем.

По данным ряда исследователей, химическая структура полимера оказывает влияние на скорости деградации ПГА (Rutkowska et al., 2008; Volova et al., 2007). Однако эти данные неоднозначны. Сополимерные образцы поли3-гидроксибутирата-со-3-гидроксивалерата (ПЗГБ/ЗГВ), имеющие меньшее значение степени кристалличности и более пористую поверхность, разрушались быстрее в тропических мангровых экосистемах, чем гомополимер поли-3-гидроксибутират (ПЗГБ) (Sridewi et al., 2006). Подобные результаты были получены при исследовании деградации образцов ПЗГБ, ПЗГБ/ЗГВ и ПЗГБ/ЗГВ/4ГБ в почве и эвтрофном озере в Малайзии. В почве быстрее разрушался терполимер, затем сополимер и медленнее всего гомополимер (Salim et al., 2012). В работе Морс и др. (Morse et al., 2011) указывают на увеличение скорости разрушения образцов поли(3-гидроксибутиратаco-3-гидроксигексаноата) при увеличении фракции сополимера с 3,8 до 10 мол. \%. Есть и противоположные результаты: например, скорость разрушения гомополимера ПЗГБ бактериями Alcaligenes faecalis выше, чем сополимера ПЗГБ/ЗГВ (Iwata et al., 1999).

Такие различия связывают с видоспецифичностью микроорганизмов-деструкторов, обладающих деполимеразной активностью, так как известно, что деградация различных по химической структуре ПГА зависит от специфичности активного сайта в каталитической области деполимеразы (Shinomiya, 1998; Kasuya, 1999).
Проведённые исследования биодеградации образцов ПГА в почве и прибрежной морской воде Южного Вьетама по некоторым параметрам не совпадали с установленными ранее закономерностями для почв и водоёмов Сибири. Например, была обнаружена более высокая скорость деградации образцов из гомополимера ПЗГБ по сравнению с сополимером ПЗГБ/ЗГВ, а также сравнительно медленная скорость убыли массы образцов в тропических почвах. Так, плёночные образцы в почве КИС Дам Бай за год экспозиции разрушились только на 50 \% (Boyandin et al., 2013). Скорость разрушения аналогичных типов полимеров в морской воде бухты Дам Бай была выше, чем в почве. За 4,5 месяца экспозиции плёнки из гомополимера ПЗГБ разрушились на $70 \%$, а из сополимера с гидроксивалератом - на 60 \% (Volova et al., 2011). Аналогичные результаты представлены в работе Салим (Salim et al., 2012), где авторы предполагают, что в почве скорость гидролиза ПГА лимитируется доступностью воды. В озере, где вода в изобилии, столкновения между молекулами воды и полимеров в единицу времени возрастают, что и приводит к увеличению скорости деградации. Такая же тенденция ранее была отмечена Ёши (Yoshie et al., 1999) в исследовании сополимера ПЗГБ/ЗГВ. Сравнительный анализ процесса биодеградации разных типов ПГА в пресной и морской воде показал, что в морской воде залива Зибурга (Канада) скорость разрушения образцов ПГА была выше, чем в пресных водоемах (Mergaert et al., 1995).

Ведущая роль микробиологической трансформации в разрушении полимерных изделий в природных средах была показана во многих работах. С увеличением численности микроорганизмов возрастала скорость деградации ПГА (Yew et al., 2006). И, наоборот, введение в полимер добавок против обраста- 
ния микроорганизмами на 100 дней задерживало начало потери массы образцов полимера в почве (Woolnough et al., 2013).

В целом, на примере различных объектов природной среды показано, что процесс биоразрушения ПГА определяется химическим составом полимера, геометрией и способом переработки полимера в изделия, типом природной экосистемы, а главным образом - её микробиологической составляющей, в зависимости от структуры которой реализуется механизм биоразрушения ПГА.

Цель настоящей работы - исследование деградации ПГА различной химической структуры в условиях тропического климата в проточных и бессточных пресных водоёмax.

\section{Материалы и методы}

Исследовали биодеградацию ПГА двух типов: гомополимера 3-гидроксимасляной кислоты (ПЗГБ) и сополимера 3-гидроксимасляной и 3-гидроксивалериановой кислот (ПЗГБ/ЗГВ) с включением 3-гидроксивалерата 8 мол. \% (Volova et al., 1998), изготовленных в виде плёнок и объёмных прессованных форм. Плёнки получали методом полива из 4\%-ных растворов полимеров в хлороформе; из плёнок высекали диски диаметром 30 мм, толщиной 0,08-0,1 мм, массой 60 \pm 10 мг. Прессованные формы получали из гомогенного порошка полимера методом прямого холодно-

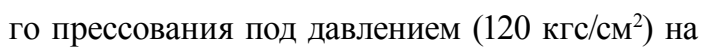
лабораторном прессе AutoPellet 3887 (Carver, США); диаметр прессованных форм 10 мм, толщина 2,5-3 мм, масса 350 \pm 5 мг.

Биодеградацию образцов полимеров исследовали в тропических условиях в проточном и бессточном водоёмах на территории Южного Вьетнама (г. Нячанг):

1 - искусственный бессточный бассейн на Климатической испытательной станции
(КИС), расположенной на острове Че в заливе Дам Бай (12 14' с.ш., $109^{\circ} 11^{\prime}$ в.д.). Удалённость от моря $\approx 50$ м. Является береговой и надводной станцией и занимает по площади 2 га на суше и 1,7 га морской акватории.

2 - естественный водоток - река Кай, протекающая в г. Нячанг (12 $17^{\prime}$ с.ш., $108^{\circ}$ $45^{\prime}-109^{\circ}$ I2' в.д.) и являющаяся основным источником водоснабжения города. Река Кай является самой большой рекой в провинции Кханьхоа, ее протяжённость - 79 км, площадь водосбора - 1450 км². Общий сток воды составляет 1,79 км³ в год. Имеет 15 притоков общей протяжённостью 10 км, впадает в залив Нячанг Южно-Китайского моря (Gusakov et al., 2011).

Подготовленные образцы полимеров помещали в чехлы из мелкоячеистого мельничного газа, по три образца каждого типа. Чехлы прикрепляли к металлическим рамкам и погружали в воду (рис. 1a, б). Глубина погружения в искусственном водоёме составляла 20-40 см. Для размещения образцов в реке Кай чехлы закрепляли в сетчатом стальном контейнере и погружали на дно реки, за чертой города выше по течению у моста (рис. 1в), глубина погружения составляла около 2 м. Период экспозиции - февраль-октябрь 2012 г.

Скорость убыли массы образцов полимеров определяли гравиметрически. Для этого чехлы один раз в месяц изымали, образцы тщательно промывали дистиллированной водой, высушивали при температуре $40{ }^{\circ} \mathrm{C}$ в течение 24 часов и взвешивали на лабораторных весах Adventurer OH-AR2140 (Ohaus, Швейцария).

Одновременно с отбором образцов регистрировали следующие гидрохимические показатели воды: температуру, рН, концентрацию растворённого кислорода, солёность. Определение содержания растворённого кислорода в воде проводили с помощью 

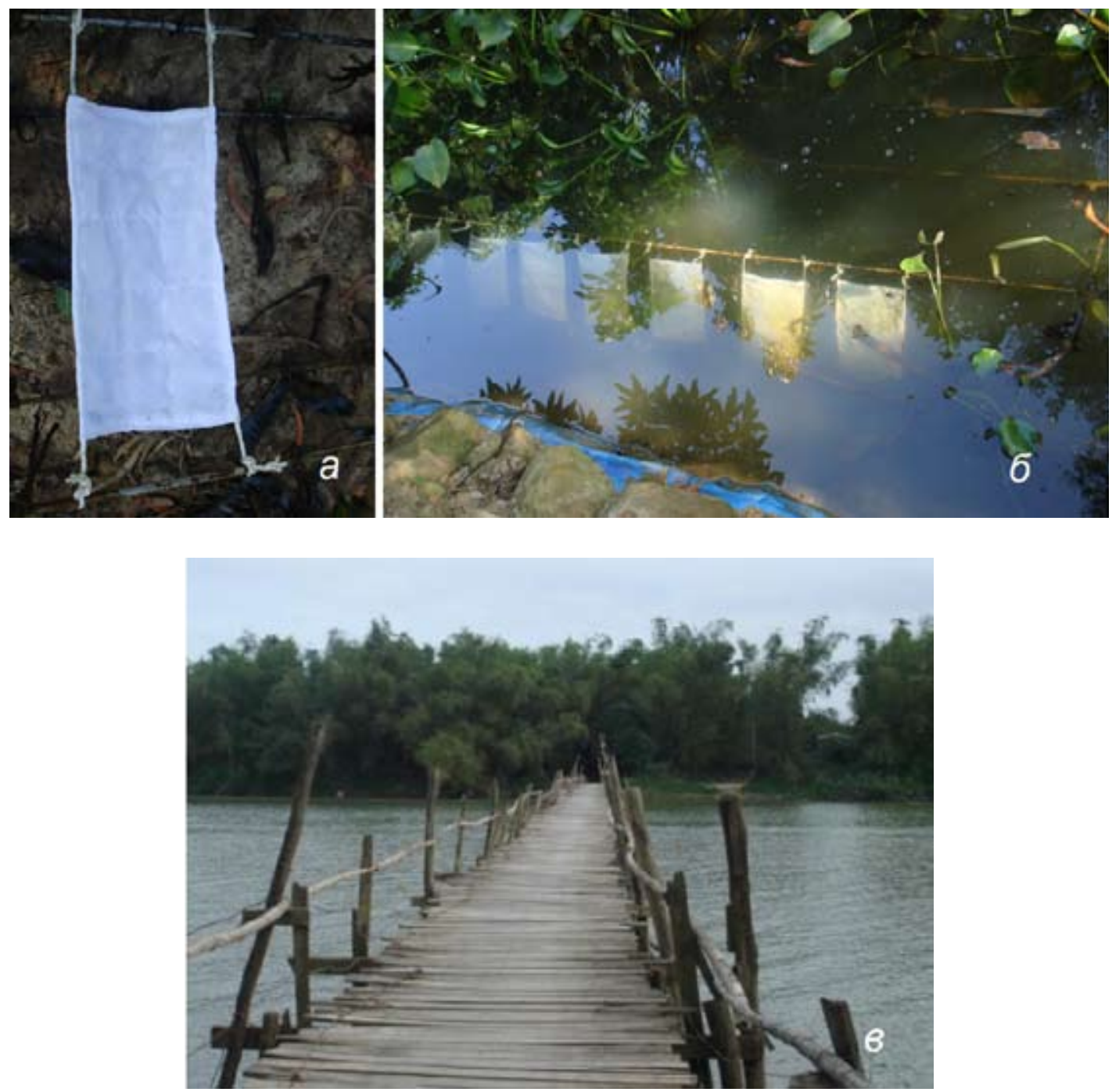

Рис. 1. Установка образцов на экспозицию: а - внешний вид чехла с образцами; б - размещение чехлов в искусственном водоеме; в - место размещения образцов в реке Кай

портативного измерителя НI 9142 (Hanna Instruments, Italia), величину $\mathrm{pH}$ - с помощью портативного рН-метра НI 98127- НI 98128 (Hanna Instruments, Italia). Солёность определяли с использованием ручного рефрактометра S/Mill-E 2442-W10 (Япония).

Анализ микрофлоры плёнок обрастания и выделение ПГА-деградирующих микроорганизмов проводили стандартными микробиологическими методами. Образцы асептически извлекали из чехла, поверхность промывали стерильной водопроводной водой, затем с поверхности методом соскоба отбирали микробиологические пробы для рассева на плотные питательные среды. Количественное определение численности бактерий в воде и на поверхности полимерных образцов проводили на универсальной питательной среде Plate count agar (PCA), г/л: пептон - 5,0; дрожжевой экстракт - 2,5; глюкоза - 1,0;

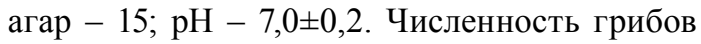
определяли на глюкозо-пептонной среде Са- 
буро и среде Чапека. Sabourou-agar, г/л: глюкоза - 40; пептон - 10; агар - 15. Czapek-agar, г/л: сахароза - 20; $\mathrm{NaNO}_{3}-2,0 ; \mathrm{K}_{2} \mathrm{HPO}_{4}-1,0$; $\mathrm{MgSO}_{4} \times 7 \mathrm{H}_{2} \mathrm{O}-0,5 ; \mathrm{KCl}-0,5 ; \mathrm{CaCO}_{3}-3,0$; агар - 20. Количество микроорганизмов рассчитывалось с учётом массы смыва. Посев производили в трёхкратной повторности из разведений до $10^{3}$. Чашки с посевами выдерживали при температуре $30^{\circ} \mathrm{C}$ для бактерий и $28^{\circ} \mathrm{C}$ для грибов. Подсчёт численности бактерий производили через 2 суток культивирования, грибов - на 4-7-е сутки.

Определение способности бактерий утилизировать ПГА проводили с использованием метода прозрачных зон (Mergaert et al., 1993), на минеральном агаре, содержащем ПГА в качестве источника углерода (г/л): $\mathrm{KH}_{2} \mathrm{PO}_{4}$ $\mathrm{Na}_{2} \mathrm{HPO}_{4}$ буфер (1:1) - 0,033 M; $\mathrm{NH}_{4} \mathrm{Cl}-1,0$; $\mathrm{MgSO}_{4} \times 7 \mathrm{H}_{2} \mathrm{O}-0,05$; цитрат железа $-0,05 ; \mathrm{CaCl}_{2}$ $\times 2 \mathrm{H}_{2} \mathrm{O}-0,005$; дрожжевой экстракт $-0,05$; гидролизат казеина - 0,1; ПГА (порошок) - 2,5; агар - 20. Для выделения микромицетовдеструкторов использовали среду следующего состава (Козловский и др., 1999), г/л: ПГА (порошок) - 5,0; $\mathrm{NaNO}_{3}-2,0 ; \mathrm{K}_{2} \mathrm{HPO}_{4}-1,0$; $\mathrm{MgSO}_{4} \times 7 \mathrm{H}_{2} \mathrm{O}-0,5 ; \mathrm{KCl}-0,5 ; \mathrm{FeSO}_{4} \times 7 \mathrm{H}_{2} \mathrm{O}-$ 0,01 ; пептон - 0,1; дрожжевой экстракт $-0,1$; агар - 20. Порошкообразный ПГА предварительно обрабатывали ультразвуком до получения мелкодисперсной суспензии. Колонии микроорганизмов-деструкторов были окружены прозрачными зонами в результате процесса гидролиза водонерастворимого полимера под воздействием внеклеточных деполиме- раз, выделяемых микроорганизмами. Идентификацию выделенных микроорганизмовдеструкторов осуществляли общепринятыми в микробиологии методами (Нетрусов и др., 2005). Для идентификации бактерий использовали набор тестов, приведенных в определителях (Boone et al., 2005; Vos et al., 2009; Whitman et al., 2012). Исследовали морфологию клеток, подвижность, способность к спорообразованию, грампринадлежность, ферментативную активность, потребность в факторах роста, способность усваивать источники углерода (на средах Гисса). Для идентификации грибов определяли культуральные признаки, особенности строения мицелия и органов спороношения (Watanabe, 2002). Микрофотографирование производили с помощью фотокамеры Sony DSC-W100 при увеличении микроскопа $\times 1000$.

\section{Результаты и обсуждение}

Известно, что условия внешней среды температура, $\mathrm{pH}$, концентрация веществ в растворе - существенно влияют на скорость деградации ПГА (Renard et al., 2004; Volova et al., 2007). Гидрохимические показатели воды в районах экспозиции образцов полимеров были подвержены небольшим колебаниям и отличались незначительно (табл. 1). Концентрация растворённого кислорода была выше в проточной воде и в течение периода наблюдений составляла от 3,1 до 3,8 мг/мл. Низкая концентрация кислорода в бессточном водоёме в сочетании со ста-

Таблица 1. Гидрохимические показатели проб воды в искусственном водоёме и в реке Кай (средние значения за время экспозиции образцов полигидроксиалканоатов)

\begin{tabular}{l|c|c|c|c}
\hline Район экспозиции & $\begin{array}{c}\text { Температура } \\
\text { воды, }{ }^{\circ} \mathrm{C}\end{array}$ & $\mathrm{pH}$ & Солёность, \%о & $\begin{array}{c}\text { Концентрация } \\
\text { кислорода, мг/мл }\end{array}$ \\
\hline КИС Дам Бай & $26,6 \pm 1,6$ & $7,2 \pm 0,2$ & $1,4 \pm 0,9$ & $1,1 \pm 0,5$ \\
Река Кай & $28,3 \pm 1,2$ & $7,1 \pm 0,1$ & $1,7 \pm 0,6$ & $3,4 \pm 0,2$ \\
\hline
\end{tabular}



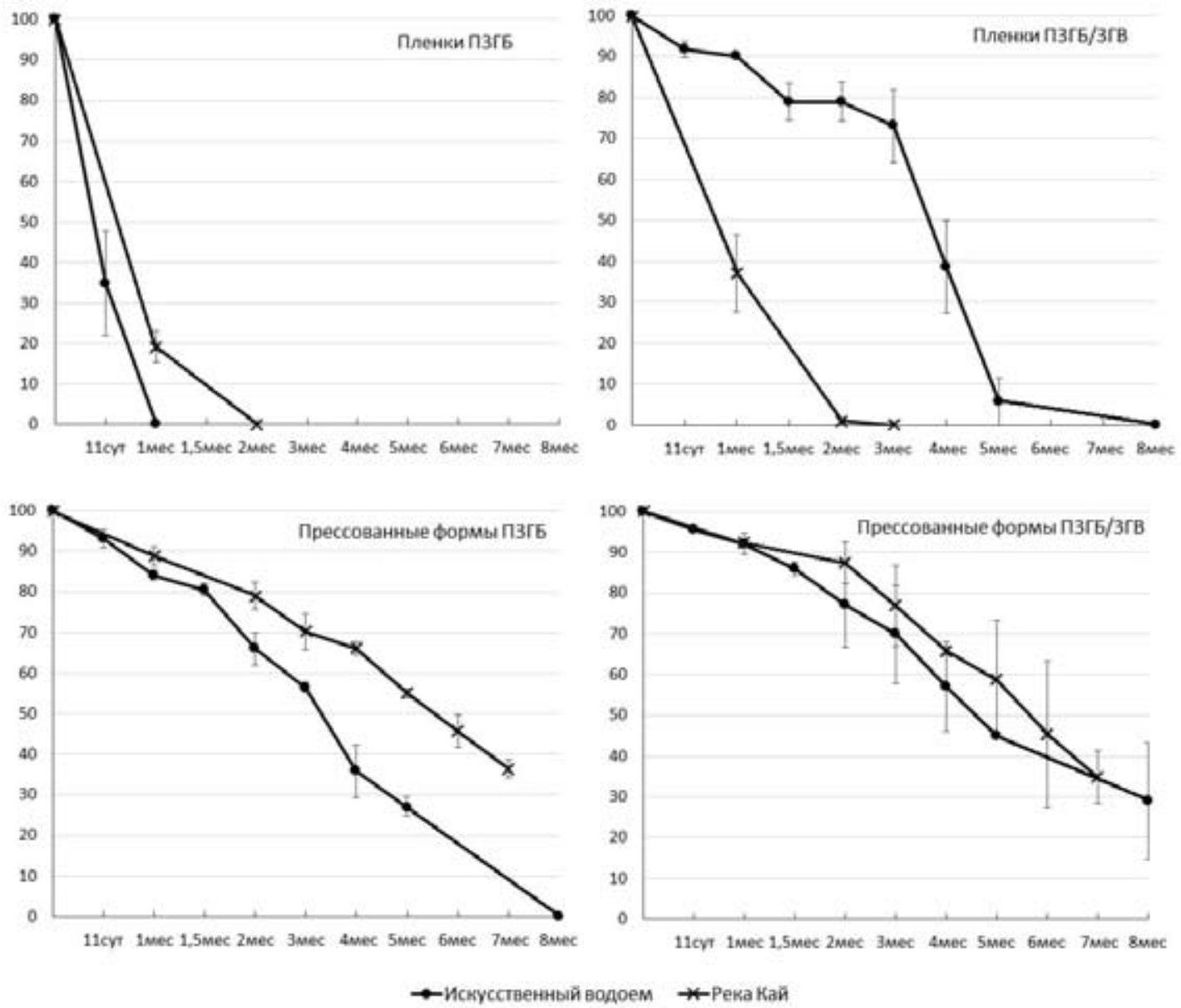

Рис. 2. Остаточная масса ( \% от исходной) образцов полимеров, экспонированных в пресной воде в условиях тропиков

бильно высокой температурой может свидетельствовать об активно протекающих процессах окисления органического вещества микроорганизмами.

В ряде работ было показано, что сополимерные образцы ПЗГБ/ЗГВ разрушаются быстрее ПЗГБ (Madden et al., 1998; Rizzarelli et al., 2004). Однако в проведённых ранее исследованиях деградации образцов ПГА в почвах Вьетнама и прибрежной морской воде Южно-Китайского моря было установлено, что гомополимер ПЗГБ разрушался быстрее его сополимера с гидроксивалератом (Volova et al., 2011; Boyandin et al., 2012).
В данной работе проводили сравнительный анализ убыли массы образцов плёнок и прессованных форм из ПЗГБ и ПЗГБ/ЗГБ, экспонированных в тропических условиях в искусственном водоёме на КИС Дам Бай и в реке Кай. Как показали наши исследования, интенсивность биодеградации образцов зависела от химической структуры полимеров и формы изделия. Скорость разрушения плёнок и прессованных форм из гомополимера была выше в искусственном водоёме (рис. 2); плёнки ПЗГБ разрушились полностью через 1 месяц, а более массивные прессованные формы - через 8 месяцев экспозиции. В реке 

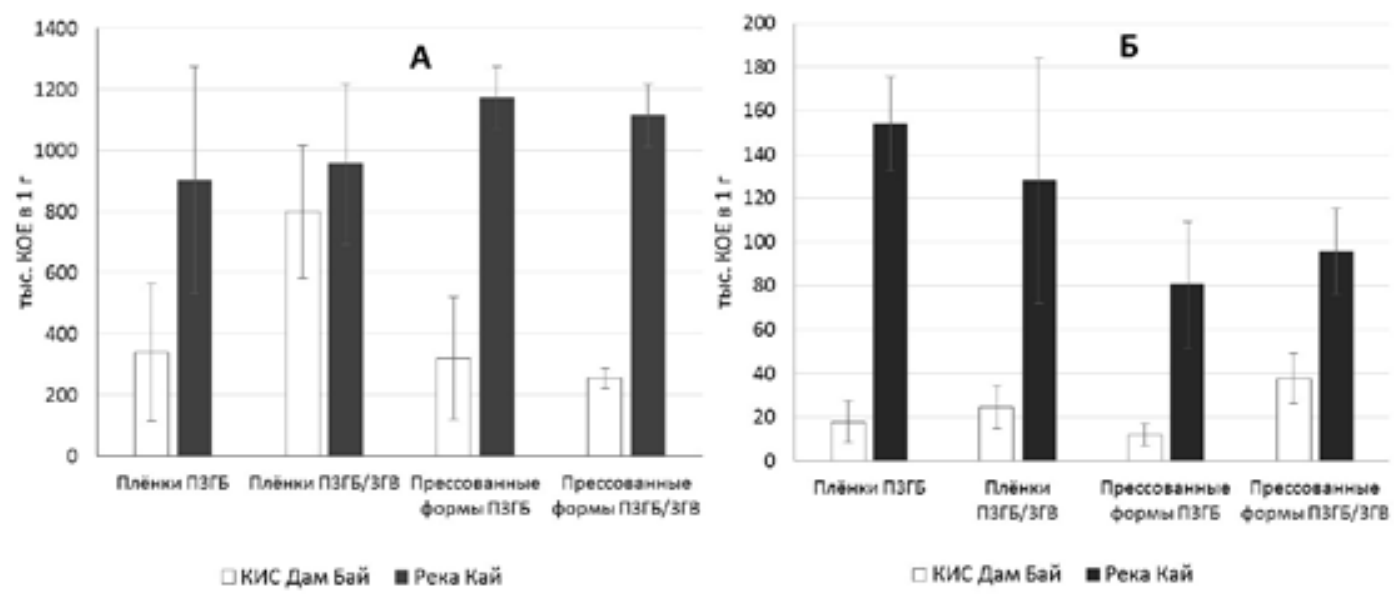

Рис. 3. Общая численность органотрофных бактерий (А) и бактерий-деструкторов (Б) в плёнках обрастания на поверхности образцов полимеров

Кай скорость разрушения прессованных форм обоих типов полимеров достоверно не различалась, остаточная масса образцов через 7 месяцев экспозиции составляла 35$36 \%$. Плёнки в реке Кай также разрушались с одинаковой интенсивностью - в течение 2 месяцев.

Иная динамика зарегистрирована в искусственном водоёме. Плёнки ПЗГБ полностью разрушились уже через месяц экспозиции, остатки же сополимерных образцов (в том числе плёночных) сохранялись и через 8 месяцев, причём для прессованных форм ПЗГБ/ЗГВ остаточная масса достигала $30 \%$. Как оказалось, скорость разрушения сополимерных образцов для бессточного водоёма была сопоставима с таковой для пруда Лесное в окрестностях г. Красноярска, описанного в работе (Volova et al., 2007).

Исходя из ведущей роли микрофлоры в процессах разрушения ПГА, в работе исследованы микробиоценозы, сформировавшиеся на поверхности образцов и принимающие участие в разрушении полимеров.

Общая численность органотрофных бактерий на поверхности плёночных об- разцов ПГА, экспонированных в различных районах, достоверно различалась и составляла $338,3 \pm 224,4$ и 799,7 $\pm 215,6$ тыс. КОЕ в 1 г на пленках ПЗГБ и ПЗГБ/3ГВ, экспонированных на КИС Дам Бай; 904,0 \pm 372,0 и $956,7 \pm 262,4$ тыс. КОЕ в 1 г на пленках, экспонированных в реке (рис. За). На поверхности объёмных прессованных форм, экспонированных в реке, численность гетеротрофных бактерий была выше в 3,5-4,3 раза, чем на аналогичных образцах из искусственного бассейна КИС Дам Бай. Если же сравнивать по водоёмам, то на образцах, изготовленных из гомо- и гетерополимера, в пределах одного района экспозиции численность достоверно не различалась.

Численность ПГА-деструкторов, проявляющих деполимеразную активность на диагностической среде с полимером, была выше на всех образцах, размещённых в реке Кай (рис. 3б). Однако на образцах разной формы и химического состава, экспонированных в одном районе, численность деструкторов достоверно не различалась и составляла от 80 до 154 тыс. КОЕ на образцах в реке Кай и от 12 до 37,7 тыс КОЕ на образцах в водоёме КИС Дам 


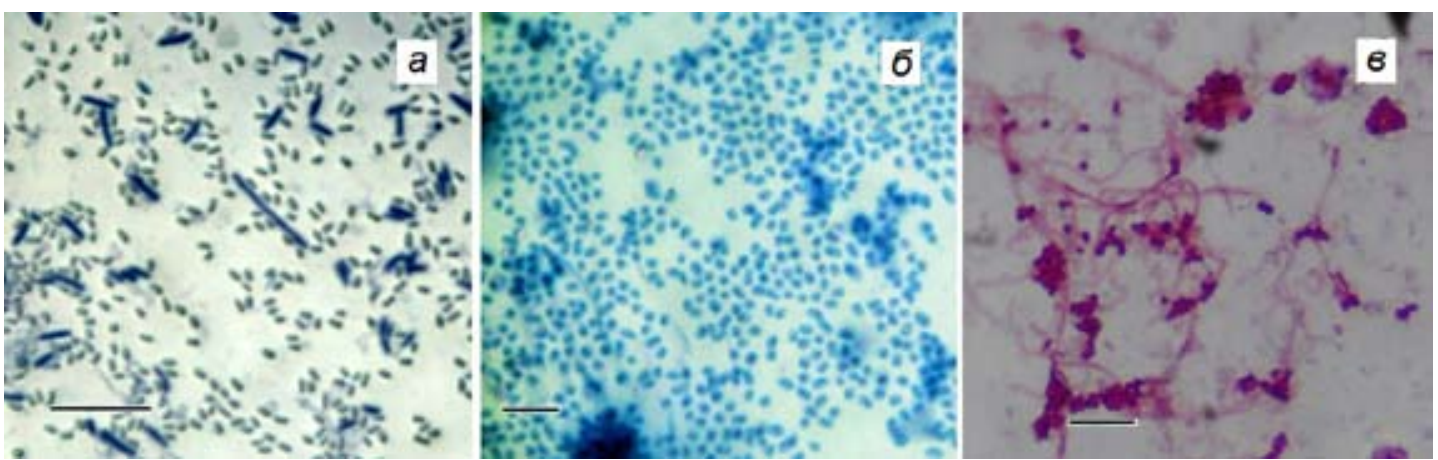

Рис. 4. Морфология бактерий-деструкторов ПГА, выделенных с поверхности образцов, экспонированных в реке Кай: a-Bacillus, б-Acinetobacter, в - Streptomyces (шкала $10 \mu \mathrm{m}$ )

Бай. В целом, доля бактерий-деструкторов в плёнках обрастания по отношению к общей численности органотрофных бактерий составляла от 3 до 17 \% для образцов разного типа.

Анализ таксономического состава микроорганизмов в биоплёнках выявил различия в структуре сообществ микроорганизмовдеструкторов ПГА в разных районах экспозиции. Из плёнок обрастания образцов ПГА, экспонированных в реке Кай, выделено 38 изолятов бактерий-деструкторов, 24 из них принадлежали к роду Bacillus, 8 - к роду Acinetobacter и 6 изолятов - актинобактерии рода Streptomyces (рис. 4).

Идентификация бактерий-деструкторов, выделенных с поверхности образцов, экспонированных в искусственном водоёме КИС Дам Бай, показала большее разнообразие представителей. Было выделено 56 изолятов бактерий-деструкторов, отнесенных к 14 штаммам: 7 штаммов бактерий, принадлежащих к четырём родам Bacillus, Pseudomonas, Corynebacterium, Mycobacterium, и 7 штаммов актинобактерий (рис. 5). Микромицеты-деструкторы были обнаружены только в искусственном водоёме - Aspergillus candidus и Verticillium alba (рис. 6).

\section{Заключение}

Таким образом, исследованы закономерности биодеградации образцов полигидроксиалканоатов в пресных тропических водоёмах Южного Вьетнама (г. Нячанг). Обнаружены различия в скоростях разрушения образцов ПГА разной химической структуры в водоёмах двух типов - проточной воде реки Кай и бессточном искусственном водоёме. Показано, что профили снижения массы плёнок и прессованных форм в реке Кай не зависели от химической структуры полимеров, образцы гомополимера 3-гидроксибутирата и сополимера 3-гидроксибутирата и 3-гидроксивалерата разрушались с одинаковой интенсивностью; плёнки за 2 месяца, прессованные формы - на 35-36 \% за 7 месяцев. В искусственном водоёме быстрее происходило разрушение образцов из гомополимера; плёнки из ПЗГБ разрушились полностью уже через месяц экспозиции, прессованные формы - через 8 месяцев; остатки образцов ПЗГБ/3ГВ сохранялись вплоть до окончания эксперимента (8 месяцев).

Выявленные различия связаны с особенностью микробного сообщества плёнок обрастания на поверхности образцов полимеров. Общая численность органотрофных бактерий и доля микроорганизмов ПГА-деструкторов 


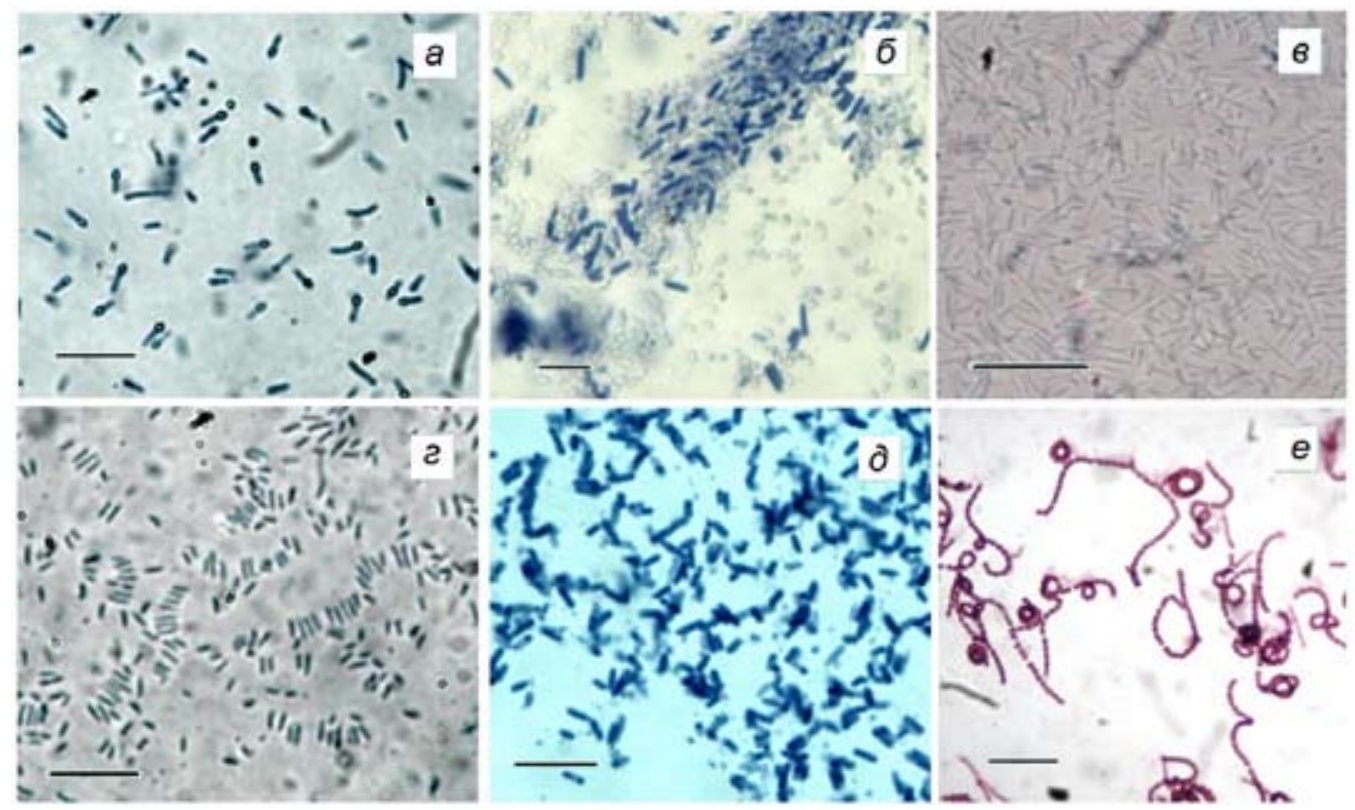

Рис. 5. Морфология бактерий-деструкторов ПГА, выделенных с поверхности образцов, экспонированных в искусственном водоёме: а, б - Bacillus, в - Pseudomonas, г-Corynebacterium, д - Mycobacterium, e Streptomyces (шкала $10 \mu \mathrm{m})$
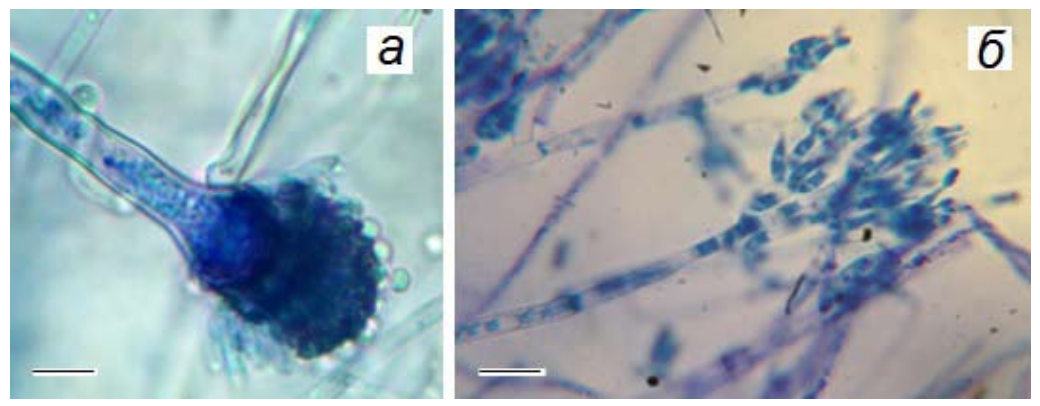

Рис. 6. Морфология конидиального спороношения грибов-деструкторов ПГА, выделенных с поверхности образцов, экспонированных в искусственном водоёме: a - Aspergillus candidus, б - Verticillium alba (шкала $10 \mu \mathrm{m})$

была выше на образцах, экспонированных в реке Кай, однако таксономический состав бактерий деструкторов был менее разнообразным. В реке Кай сообщество деструкторов было представлено бактериями родов Bacillus, Acinetobacter и Streptomyces, а в искусственном водоёме - представителями родов Bacillus, Pseudomonas, Corynebacterium, Mycobacterium, а также актинобактериями.
Микромицеты-деструкторы были обнаружены только в искусственном водоёме Aspergillus candidus и Verticillium alba. Полученные результаты подтверждают ведущую роль микроорганизмов в трансформации ПГА за счёт образования специфических ПГА-деполимераз, активных в отношении полимеров различной химической структуры. 
Работа выполнена за счет средств государственного задания на проведение фундаментальных исследований РАН (проект № гос. регистрации 01201351505 ).

\section{Список литературы}

1. Козловский А.Г., Желифонова В.П., Винокурова Н.Г., Антипова Т.В., Иванушкина Н.Е. (1999) Изучение биодеградации поли-ß-гидроксибутирата микроскопическими грибами. Микробиология 68(3): 360-346. [Kozlovsky A.G., Zhelifonova V.P., Vinokourov N.G., Antipova T.V., Ivanushkina N.E. (1999) The study of biodegradation of poly-ß-hydroxybutyrate by microscopic fungi. Microbiology 68(3): 360-346. (In Russian)]

2. Нетрусов А.И., Егорова М.А., Захарчук Л.М. (2005) Практикум по микробиологии. Под ред. А.И. Нетрусова. М.: Академия, 608 с. [Netrusov A.I., Egorov M.A., Zakharchuk L.M. (2005) Workshop on microbiology. Ed. A.I. Netrusov. M.: Academy, 608p. (In Russian)]

3. Boone D.R., Castenholz R.W., Garrity G.M., Brenner D.J., Krieg N.R., Staley J.T. (Eds.) (2005) Bergey's Manual ${ }^{\circledR}$ of Systematic Bacteriology. Vol. 2. New York: Springer Science \& Business Media.

4. Boyandin A.N., Prudnikova S.V., Karpov V.A., Ivonin V.N., Đỗ N.L., Nguyễn T.H., Gitelson I.I. (2013). Microbial degradation of polyhydroxyalkanoates in tropical soils. International Biodeterioration \& Biodegradation 83: 77-84.

5. Boyandin A.N., Rudnev V.P., Ivonin V.N., Prudnikova S.V., Korobikhina K.I., Filipenko M.L., Sinskey A.J. (2012) Biodegradation of polyhydroxyalkanoate films in natural environments. Macromolecular Symposia 320(1): 38-42.

6. Iwata T., Doi Y., Nakayama S.I., Sasatsuki H., Teramachi S. (1999). Structure and enzymatic degradation of poly (3-hydroxybutyrate) copolymer single crystals with an extracellular PHB depolymerase from Alcaligenes faecalis T1. International Journal of Biological Macromolecules 25(1): 169-176.

7. Gusakov V.A., Gagarin V.G., Gusev E.S. (2011) The first results of meiobenthos study in the Cái River (Central Vietnam). Inland Water Biology 4(3): 357-366.

8. Kasuya K.I., Ohura T., Masuda K., Doi Y. (1999). Substrate and binding specificities of bacterial polyhydroxybutyrate depolymerases. International Journal of Biological Macromolecules 24(4): 329-336.

9. Madden L.A., Anderson A.J., Asrar J. (1998). Synthesis and characterization of poly (3-hydroxybutyrate) and poly (3-hydroxybutyrate-co-3-hydroxyvalerate) polymer mixtures produced in high-density fed-batch cultures of Ralstonia eutropha (Alcaligenes eutrophus). Mac romolecules 31(17): 5660-5667.

10. Mergaert J., Webb A., Anderson C., Wouters A., Swings J. (1993). Microbial degradation of poly (3-hydroxybutyrate) and poly (3-hydroxybutyrate-co-3-hydroxyvalerate) in soils. Applied and Environmental Microbiology 59(10): 3233-3238.

11. Mergaert J., Wouters A., Swings J., Anderson C. (1995). In situ biodegradation of poly (3-hydroxybutyrate) and poly (3-hydroxybutyrate-co-3-hydroxyvalerate) in natural waters. Canadian Journal of Microbiology 41(13): 154-159.

12. Morse M.C., Liao Q., Criddle C.S., Frank C.W. (2011). Anaerobic biodegradation of the microbial copolymer poly(3-hydroxybutyrate-co-3-hydroxyhexanoate): Effects of comonomer content, processing history, and semi-crystalline morphology. Polymer 52(2): 547-556. 
13. Rizzarelli P., Puglisi C., Montaudo G. (2004) Soil burial and enzymatic degradation in solution of aliphatic co-polyesters. Polymer Degradation and Stability 85(2): 855-863.

14. Renard E., Walls M., Guérin P., Langlois V. (2004). Hydrolytic degradation of blends of polyhydroxyalkanoates and functionalized polyhydroxyalkanoates. Polymer Degradation and Stability 85(2): 779-787.

15. Rutkowska M., Krasowska K., Heimowska A., Adamus G., Sobota M., Musioł M., Kowalczuk M. (2008). Environmental degradation of blends of atactic poly [(R, S)-3-hydroxybutyrate] with natural PHBV in Baltic Sea water and compost with activated sludge. Journal of Polymers and the Environment 16(3): 183-191.

16. Salim Y.S., Sharon A., Vigneswari S., Ibrahim M.M., Amirul A.A. (2012) Environmental degradation of microbial polyhydroxyalkanoates and oil palm-based composites. Applied Biochemistry and Biotechnology 167(2): 314-326.

17. Shinomiya M., Iwata T., Doi Y. (1998). The adsorption of substrate-binding domain of PHB depolymerases to the surface of poly (3-hydroxybutyric acid). International Journal of Biological Macromolecules 22(2): 129-135.

18. Sridewi N., Bhubalan K., Sudesh K. (2006). Degradation of commercially important polyhydroxyalkanoates in tropical mangrove ecosystem. Polymer Degradation and Stability 91(12): 2931-2940.

19. Volova T.G., Boyandin A.N., Vasil'ev A.D., Karpov V.A., Kozhevnikov I.V., Prudnikova S.V., Gitel'Zon I.I. (2011) Biodegradation of polyhydroxyalkanoates (PHAs) in the South China Sea and identification of PHA-degrading bacteria. Microbiology 80(2): 252-260.

20. VolovaT.G.,GladyshevM.I.,Trusova M.Y.,ZhilaN.O.(2007)Degradation of polyhydroxyalkanoates in eutrophic reservoir. Polymer Degradation and Stability 92(4): 580-586.

21. Volova T.G., Kalacheva G.S., Plotnikov V.F. (1998) Biosynthesis of heteropolymeric polyhydroxyalkanoates by chemolithoautotrophic bacteria. Microbiology 67(4): 420-424.

22. Vos P., Garrity G., Jones D., Krieg N.R., Ludwig W., Rainey F.A., Schleifer K.-H., Whitman W. (Eds.) (2009) Bergey's Manual ${ }^{\circledR}$ of Systematic Bacteriology. Vol. 3. Springer Science \& Business Media.

23. Watanabe T. (2002) Pictorial atlas of soil and seed fungi: morphologies of fungi and key species. CRC Press: 486.

24. Whitman W., Goodfellow M., Kämpfer P., Busse H.-J., Trujillo M., Ludwig W., Suzuki K.-I., Parte A. (Eds.). (2012). Bergey's Manual ${ }^{\circledR}$ of Systematic Bacteriology. Vol. 5. New York: Springer Science \& Business Media.

25. Woolnough C.A., Yee L.H., Charlton T.S., Foster L.J.R. (2013) A tuneable switch for controlling environmental degradation of bioplastics: addition of isothiazolinone to polyhydroxyalkanoates. PloS One 8(10): e75817.

26. Yew S.P., Tang H.Y., Sudesh K. (2006) Photocatalytic activity and biodegradation of polyhydroxybutyrate films containing titanium dioxide. Polymer Degradation and Stability 91(8): 1800-1807.

27. Yoshie N., Fujiwara M., Kasuya K.I., Abe H., Inoue Y. (1999). Effect of monomer composition and composition distribution on enzymatic degradation of poly (3-hydroxybutyrate-co-3-hydroxyvale rate). Macromolecular Chemistry and Physics 200(5): 977-982. 